\title{
Pharmacokinetic studies on Sulfamonomethoxine in rabbits
}

\author{
Amer, M.S. ${ }^{1}$; M. G. Elsayed; Kazawaki ${ }^{2}$, S. WM Fathy ${ }^{3}$ and Eman S. El-Ashry ${ }^{1}$ \\ ${ }^{1}$ Pharmacology Department, Faculty of Veterinary Medicine, Mansoura University \\ ${ }^{2}$ Pharmacology Department, Tokyo University of Agriculture and Technology \\ ${ }^{3}$ Pharmacology Department, Faculty of Veterinary Medicine, Suez Canal University
}

\section{ABSTRACT}

\begin{abstract}
The present study was performed to determine the pharmacokinetics of sulfamonomethoxine $(20 \mathrm{mg} / \mathrm{kg})$ in 5 rabbits after its oral and intravenous administration. Blood samples were collected immediately before (time 0 ) and at $0.08,0.25,0.5,1,3,5$ and 8 hours post-dosing to evaluate the pharmacokinetics of sulfamonomethoxine. Plasma sulfamonomethoxine concentrations were quantified with HPLC-UV, and plasma drug concentration versus time data after IV was best fitted to the two-compartment model, characterized with the distribution phase $(\alpha)$ equaled to $2.05 \mathrm{~h}^{-1}$ with a distribution half-life $\left[\mathrm{t}_{0.5(\alpha)}\right]$ equaled to $0.61 \mathrm{~h}$. The volume of distribution of $\left(\mathrm{V}^{1}{ }_{\mathrm{c}}\right)$ was $0.15 \mathrm{ml} / \mathrm{kg}$., whereas the volume of distribution at a steady - state $\left[\mathrm{V}_{\mathrm{dss}}\right]$ was $0.20 \mathrm{ml} / \mathrm{kg}$, and the body clearance was $0.03 \mathrm{ml} / \mathrm{kg} / \mathrm{h}$. After oral administration of SMM, plasma drug concentrations were best fitted to a two-compartment model, of which the mean half-life of absorption $\left(\mathrm{t} 1 / 2_{\mathrm{ab}}\right)$ and elimination $\left(\mathrm{t} 1 / 2_{\beta}\right)$ were 0.02 and $1.99 \mathrm{~h}$, respectively. The maximal absorption concentration (Cmax) was estimated as $114.06 \mu \mathrm{g} / \mathrm{ml}$ at $0.12 \mathrm{~h}$, and the Area under the curve (AUC) was $340.42 \mu \mathrm{g} / \mathrm{ml} / \mathrm{h}$.
\end{abstract}

Keywords: rabbits; sulfamonomethoxine

\section{INTRODUCTION}

Rabbit production has already attained commercial status in many parts of the world as a source of protein. The users prefer rabbits for their low cholesterol and fat contents. Therefore, rabbit manufacture became one of the important animal resources in Egypt. In addition to this commercial value, these animals are used as very important models for medical research (Okerman, 1994).

Sulfonamides widely used antibacterial agents in the world, chiefly because of their low cost, low toxicity, and excellent activity against common bacterial diseases. Sulfonamides with the antimicrobial activity represent a large group of drugs which can be classified in different groups, according to the duration of action and half-life; absorbable oral sulfonamides can be further divided into Short-acting, Intermediate-acting, and Long-acting sulfonamides. Oral sulfonamides which cannot be absorbed fulfill their role in the gastrointestinal tract, while topical sulfonamides amides can be used in the treatment of skin and mucous membrane infections and burns. (Tačić et al., 2017)

Nowadays, sulfonamides are active against both grampositive and gram-negative bacteria. Sulfonamides are most frequently used in treatment of urinary tract infections caused by susceptible strains of bacteria. However, recurrent urinary tract infections are usually caused by pathogens resistant to sulfonamides (Ronald, 2003 ).

Sulfamonomethoxine

(6-sulfanilamide-4methoxypyrimidine), a sulfanilamide with long-lasting action in a series of cases exceeds sulfadimethoxine and sulfapyridazine in therapeutic activity. Sulfamonomethoxine, normally administered via food, is widely used for therapeutic or prophylactic proposes for food-producing animal diseases, due to its wide spectrum of antibacterial activity and economic advantage gained from its application. It was relatively rapidly resorbed from the gastrointestinal system and circulated in the blood for a long time. (Connor, 1998)

The pharmacokinetics of Sulfamonomethoxine is necessary: it is essential to know the dependence of plasma drug concentration/ biotransformation on the time elapsed since administration. So, the present study aimed to determine the pharmacokinetic of sulfamonomethoxine in plasma after oral and intravenous injection to rabbits.

\section{MATERIALS AND METHODS}

\subsection{Drugs}

Sulfamonomethoxine (Daimeton ${ }^{\circledR}$ ) was obtained as a sodium salt powder from Daiichi Pharmaceutical Company 
(Tokyo, Japan). Sodium Acetate Trihydrate, Acetonitrile (CH3CN), Perchloric acid (HCLO4) 60\%, Methanol and glacial Acetic Acid $(\mathrm{CH} 3 \mathrm{COOH})$ were obtained from Wako Pure Chemical Industries, Ltd. (Osaka, Japan). Ethylenediaminetetraacetic acid (EDTA) was purchased from Dojindo Molecular Technologies, CO. Japan) in the form

\subsection{Experimental Animals:}

Five rabbits were maintained in accordance with the recommendations of the 'Guide for the Care and Use of Laboratory Animals' approved by the Faculty of Agriculture, Tokyo University of Agriculture and Technology. They were clinically healthy and weighing $2.5 \sim 3.5 \mathrm{~kg}$. These rabbits were housed in cages at ambient temperature and with good ventilation. Animals were fed pellets twice a day with water ad libitum.

\subsection{Experimental Design for drugs:}

The experiment was conducted on five rabbits. The drug was dissolved in sterilized distilled water and administered either into the left ear vein or orally by stomach tube to rabbits at dose of $20 \mathrm{mg} / \mathrm{kg}$ for each route using a crossover design with at least a 3-week washout period.

\subsection{Preparation of stock solutions and standards (calibration curve) for plasma}

Standard stock solution of SMM $(1 \mathrm{mg} / \mathrm{mL})$ was prepared by dissolving about $10 \mathrm{mg}$ of powder and added distilled water until $10 \mathrm{ml}$ in volumetric flask also, SMM calibration standards were prepared at $0.1,0.2,0.5,0.8,1.5,3.5,6.5,12.5$ and $25 \mu \mathrm{g}$ $/ \mathrm{ml}$ using blank rabbit plasma as a diluent.

\subsection{Preparation of Mobile Phase for SMM:}

The mobile phase for plasma was a mixture of $50 \mathrm{mM}$ acetate buffer $(\mathrm{pH}$ is 5$)$ and acetonitrile $(80: 20 \mathrm{v} / \mathrm{v})$ and acetate buffer was prepared by dissolving about $6.08 \mathrm{gm}$. of sodium acetate trihydrate crystal powder and added distilled water until 1 liter and adjust PH to 5 by adding acetic acid (Elbadawy et al., 2015).

\subsection{Blood sample:}

Blood samples ( $1 \mathrm{ml}$ for each sample) were collected from the right ear vein immediately prior to the treatment and at $0.08,0.25,0.5,1,3,5$ and $8 \mathrm{~h}$ post dosing. The samples were placed in tubes containing EDTA and centrifuged at 2,000 g for $10 \mathrm{~min}$ and the plasma samples were stored at $-20^{\circ} \mathrm{C}$ until analysis.

\subsection{Sample preparation for HPLC:}

One hundred microliters of perchloric acid $\left(\mathrm{HCLO}_{4}\right)$ were added to $100 \mu \mathrm{l}$ of the plasma sample. The mixture was vortex for $30 \mathrm{~s}$ and then centrifuged at $20,000 \mathrm{~g}$ for $5 \mathrm{~min}$ at $5^{\circ} \mathrm{C}$. The obtained supernatant was filtered using the $0.45-\mu \mathrm{m} \mathrm{HPLC}$ filter. Fifty microliters of the filtrate were injected into the HPLC column.

\subsection{The condition of liquid chromatography:}

Sulfamonomethoxine concentrations were determined in the plasma by the previously described HPLC method with UVdetection (Elbadawy et al., 2015). Analytical separation for SMM was accomplished using a reversed-phase $\mathrm{C}_{8}$ column (Mightysil RP-8 GP, $4.6 \mu \mathrm{m} \times 250 \mathrm{~mm}$, Kanto Chemical Co., Tokyo, Japan). The flow rate was $1 \mathrm{ml} / \mathrm{min}$ and the wavelength of the detector was $270 \mathrm{~nm}$ for both drugs. The recovery from plasma samples in SMM was $101.7 \pm 4.34 \%$ at $1 \mu \mathrm{g} / \mathrm{ml}(\mathrm{n}=5)$.

\subsection{Pharmacokinetic analysis:}

The plasma concentration-time curves of SMM after the intravenous injection fit well with the two-compartment model, while after oral administration fit well with the one compartment model. Therefore, the curves obtained after the intravenous injection $\left(\mathrm{Cp}_{\mathrm{iv}}(\mathrm{T})\right)$ and those after the oral administration $\left(C p_{p o}(T)\right)$ were described by Eq. 1 and 2, respectively. $\mathrm{Cp}_{\mathrm{iv}}(\mathrm{T})=\mathrm{A} * \operatorname{EXP}\left(-\mathrm{ALPHA}{ }^{*} \mathrm{~T}\right)+\mathrm{B} * \operatorname{EXP}\left(-\mathrm{BETA}{ }^{*} \mathrm{~T}\right)$ $C p_{p o}(T)=D^{*} K 01 / V /(K 01-K 10) *(\operatorname{EXP}(-K 10 * T)-\operatorname{EXP}(-K 01 * T))$

\subsection{Statistical Analysis:}

Data were subjected to statistical analysis using Mean \pm SE.

\section{RESULTS}

\subsection{A standard curve of Sulfamonomethoxine:}

Sulfamonomethoxine standard concentrations of $0.1,0.2$, $0.5,0.8,1.5,3.5,6.5,12.5$ and $25 \mu \mathrm{g} / \mathrm{ml}$ and their corresponding peak response (Area under curve) were illustrated in Table (1) and shown in Figure (1). Linearity existed within range of 0.1 and $25 \mu \mathrm{g} / \mathrm{ml}$ with a correlation coefficient $\left(r^{2}=0.999\right)$.

Table 1.Concentrations of sulfamonomethoxine standard $(\mu \mathrm{g} / \mathrm{ml})$ and their corresponding response (area under the curve).

$\begin{array}{ll}\text { Area under curve }(\mathrm{mAu} * \mathrm{~min}) & \text { Concentration }(\mu \mathrm{g} / \mathrm{ml}) \\ 0.1 & 17265 \\ 0.2 & 32804 \\ 0.5 & 62327 \\ 0.8 & 118421 \\ 1.5 & 225000 \\ 3.5 & 427500 \\ 6.5 & 812250 \\ 12.5 & 1543275 \\ 25 & 2932223\end{array}$




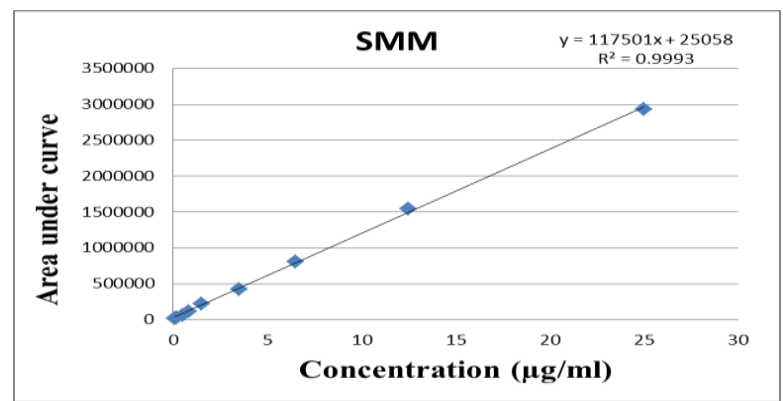

Figure 1. Standard curve of Sulfamonomethoxine in rabbit plasma

\section{B.2. Pharmacokinetic studies of sulfamonomethoxine after a} single IV injection

The mean plasma concentrations of sulfamonomethoxine following a single IV injection at dose of $20 \mathrm{mg} / \mathrm{kg}$ in rabbits were recorded in Table (2) and in Figure (2).

The recorded results showed that the plasma concentration of Sulfamonomethoxine was $123.96 \pm$ 1.71at $0.08 \mathrm{~h}$ post injection then decreased gradually till reach 9.02 \pm 0.78 at $8 \mathrm{~h}$ post administration.

The pharmacokinetic parameters of Sulfamonomethoxine after IV administration were recorded in Table (3). The distribution phase $(\alpha)$ equaled to $2.27 \pm 0.41 \mathrm{~h}^{-1}$ with a distribution half - life $\left[t_{0.5(\alpha)}\right]$ equaled to $0.33 \pm 0.05 \mathrm{~h}$. The volume of distribution of Sulfamonomethoxine to the central compartment $\left(V_{c}^{1}\right)$ was $0.15 \pm 0.003 \mathrm{ml} / \mathrm{kg}$., whereas the volume of distribution at a steady - state $\left[\mathrm{V}_{\mathrm{dss}}\right]$ was $0.18 \pm$ $0.002 \mathrm{ml} / \mathrm{kg}$.

Sulfamonomethoxine was transferred from central to peripheral compartment $\left(K_{12}\right)$ at $0.44 \pm 0.11 \mathrm{~h}^{-1}$ while its passage from the peripheral to the central compartment $\left(\mathrm{K}_{21}\right)$ equal to $1.80 \pm 0.27 \mathrm{~h}^{-1}$. Sulfamonomethoxine was eliminated after intravenous injection with half - life $\left[\mathrm{t}_{0.5(\beta)}\right]$ value of 2.54 $\pm 0.15 \mathrm{~h}$ and cleared from the body $(\mathrm{CL})$ at a rate of $0.05 \pm$ $0.003 \mathrm{ml} / \mathrm{kg} / \mathrm{h}$. The peak plasma concentration $\left(C_{\max }\right)$ was $132.72 \pm 2.82 \mu \mathrm{g} / \mathrm{ml}$.

The area under curve (AUC) was $376.60 \pm 17.75 \mu \mathrm{g} / \mathrm{ml} / \mathrm{h}$, the area under first moment curve (AUMC) was $1303.07 \pm 113.30 \mu \mathrm{g} / \mathrm{ml} / \mathrm{h}^{2}$ and the mean residence time (MRT) was $3.43 \pm 0.16 \mathrm{~h}$

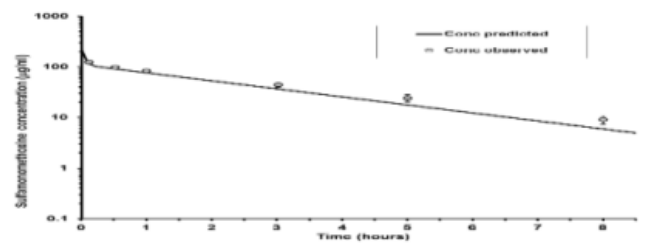

Figure 2. plasma concentration-time profile of Sulfamonomethoxine following a single IV injection of $20 \mathrm{mg} / \mathrm{kg}$ in rabbits. (Mean \pm S.E). $(n=5)$.
Table 3. Pharmacokinetic parameters of Sulfamonomethoxine $(\mu \mathrm{g} / \mathrm{ml})$ following a single IV injection $(20 \mathrm{mg} / \mathrm{kg})$ in rabbits. (Mean \pm S.E). $(n=5)$.

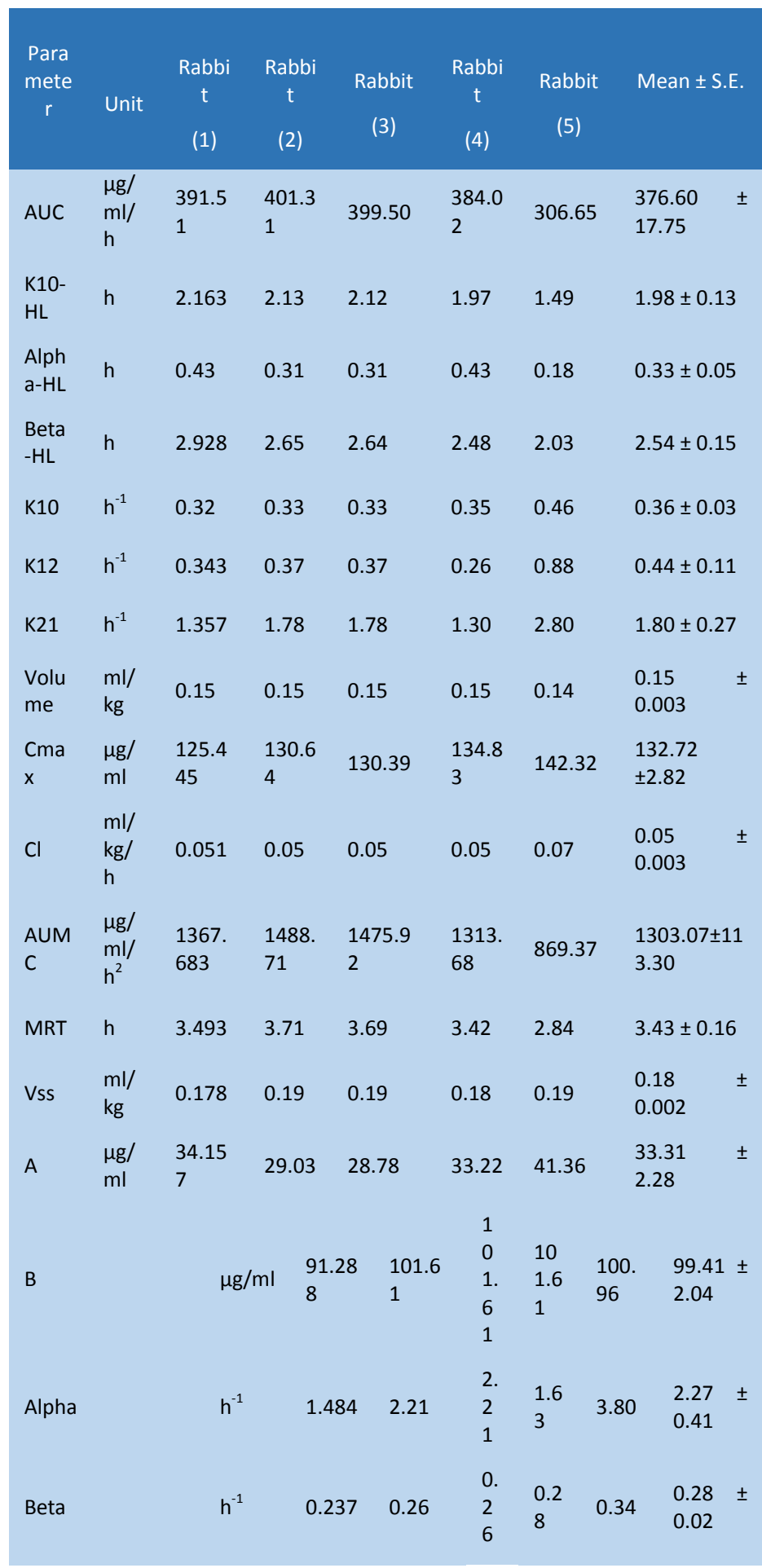

A.3. Pharmacokinetic studies of sulfamonomethoxine after a single oral dose administration: 
The mean plasma concentrations of sulfamonomethoxine following a single (PO) administration of $20 \mathrm{mg} / \mathrm{kg}$ in rabbits were recorded in Table (4) and in Figure (3).

The recorded results revealed that the plasma concentration of sulfamonomethoxine was $120.67 \pm 1.75$ at $0.08 \mathrm{~h}$ post injection then decreased gradually till reach $9.95 \pm 0.81$ at $8 \mathrm{~h}$ post administration.

The pharmacokinetic parameters of sulfamonomethoxine after $P O$ administration were recorded in Table (5). The obtained results showed that the absorption rate constant $\left(K_{a b}\right)$ was $56.04 \pm 13.90 \mathrm{~h}^{-1}$, while absorption half-life $\left[t_{0.5(a b)}\right]$ was $(0.02 \pm 0.006 \mathrm{~h})$.

Table 2. Plasma concentrations of Sulfamonomethoxine $(\mu \mathrm{g} / \mathrm{ml})$ following a single IV injection $(20 \mathrm{mg} / \mathrm{kg}$ ) in rabbits. (Mean $\pm \mathrm{S}$.E) $(n=5)$.

\begin{tabular}{|c|c|c|c|c|c|c|}
\hline Rabbits & & lasma ce & icentrati & ( $(\mu \mathrm{g} / \mathrm{ml}$ & & \\
\hline $\begin{array}{l}\text { Time } \\
\text { post } \\
\text { dosing } \\
\text { (h) }\end{array}$ & $\begin{array}{l}\text { Rabbit } \\
\text { (1) }\end{array}$ & $\begin{array}{c}\text { Rabbit } \\
\text { (2) }\end{array}$ & $\begin{array}{c}\text { Rabbit } \\
\text { (3) }\end{array}$ & $\begin{array}{l}\text { Rabbit } \\
\text { (4) }\end{array}$ & $\begin{array}{l}\text { Rabbit } \\
\text { (5) }\end{array}$ & $\begin{array}{c}\text { Mean } \bar{X} \pm \\
\text { S.E. }\end{array}$ \\
\hline $\begin{array}{c}0.08 \\
(5 \mathrm{~min})\end{array}$ & 118.02 & 123.70 & 123.57 & 128.19 & 126.30 & $\begin{array}{c}123.96 \pm \\
1.71\end{array}$ \\
\hline $\begin{array}{c}0.5 \\
(30 \mathrm{~min})\end{array}$ & 105.78 & 95.99 & 95.86 & 101.63 & 87.76 & $\begin{array}{l}97.41 \\
\pm 2.14\end{array}$ \\
\hline 1 & 87.60 & 85.46 & 85.33 & 85.12 & 75.423 & $\begin{array}{l}83.79 \\
\pm 3.05\end{array}$ \\
\hline 3 & 42.02 & 47.57 & 47.44 & 47.19 & 36.18 & $\begin{array}{l}44.08 \\
\pm 2.23\end{array}$ \\
\hline 5 & 25.80 & 27.10 & 26.96 & 23.19 & 17.64 & $\begin{array}{l}24.14 \\
\pm 1.77\end{array}$ \\
\hline 8 & 10.57 & 9.91 & 9.79 & 8.74 & 6.12 & $\begin{array}{c}9.02 \\
\pm 0.78\end{array}$ \\
\hline
\end{tabular}

Sulfamonomethoxine was eliminated at a rate $\left(K_{e l}\right)$ equal to $0.35 \pm 0.02 \mathrm{~h}^{-1}$, with elimination half-life ( $\left[\mathrm{t}_{0.5 \mathrm{el}}\right]$ of $1.99 \pm 0.10 \mathrm{~h}$ and the volume of distribution (V/F) was $0.17 \pm 0.003 \mathrm{ml} / \mathrm{kg}$. Sulfamonomethoxine was cleared from the the body at a rate of $0.06 \pm 0.003 \mathrm{ml} / \mathrm{kg} / \mathrm{h}$. The peak plasma concentration $\left(C_{\max }\right)$ was $114.06 \pm 1.17 \mu \mathrm{g} / \mathrm{ml}$ and obtained at $\left(T_{\max }\right)$ of $0.12 \pm$ $0.03 \mathrm{~h}$ post injection. (AUC) was $340.42 \pm 14.54 \mu \mathrm{g} / \mathrm{ml} / \mathrm{h}$.

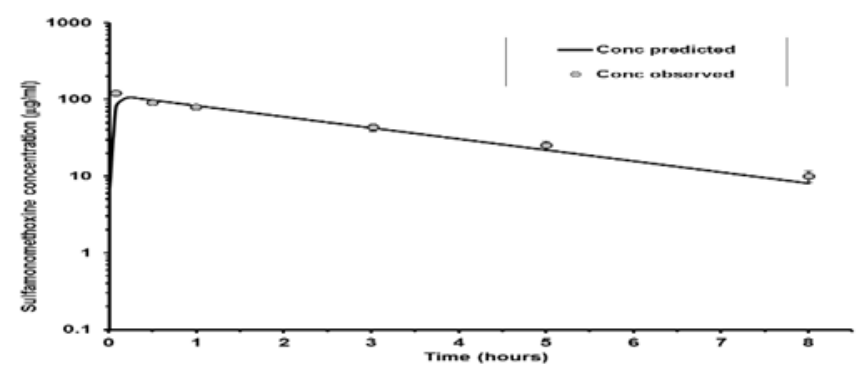

Figure 3. Plasma concentration-time profile of sulfamonomethoxine following a single $\mathrm{PO}$ administration of $20 \mathrm{mg} / \mathrm{kg}$ in rabbits. (Mean $\pm S . E)$. $(n=5)$
Table 4. Plasma concentration of sulfamonomethoxine $(\mu \mathrm{g} / \mathrm{ml})$ following a single PO administration $(20 \mathrm{mg} / \mathrm{kg}$ ) in rabbits. (Mean \pm S.E). $(n=5)$

\begin{tabular}{|c|c|c|c|c|c|c|}
\hline \multirow[b]{2}{*}{$\begin{array}{l}\text { Rabbits } \\
\text { Time after } \\
\text { dosing (h) }\end{array}$} & \multicolumn{5}{|c|}{ Plasma concentration $(\mu \mathrm{g} / \mathrm{ml})$} & \multirow[b]{2}{*}{ Mean $\bar{X} \pm$ S.E. } \\
\hline & $\begin{array}{c}\text { Rabbit } \\
\text { (1) }\end{array}$ & $\begin{array}{c}\text { Rabbit } \\
(2)\end{array}$ & $\begin{array}{c}\text { Rabbit } \\
\text { (3) }\end{array}$ & $\begin{array}{c}\text { Rabbit } \\
\text { (4) }\end{array}$ & $\begin{array}{c}\text { Rabbit } \\
\text { (5) }\end{array}$ & \\
\hline $0.08(5 \mathrm{~min})$ & 114.31 & 122.69 & 119.66 & 122.50 & 124.18 & $120.67 \pm 1.75$ \\
\hline $0.5(30 \mathrm{~min})$ & 92.27 & 83.13 & 99.58 & 89.90 & 89.83 & $90.94 \pm 2.64$ \\
\hline 1 & 80.10 & 75.56 & 88.98 & 76.68 & 74.860 & $79.41 \pm 2.62$ \\
\hline 3 & 45.34 & 49.82 & 43.66 & 38.42 & 38.171 & $43.08 \pm 2.20$ \\
\hline 5 & 24.53 & 26.70 & 27.29 & 27.86 & 19.811 & $25.24 \pm 1.47$ \\
\hline 8 & 9.96 & 10.32 & 11.29 & 11.29 & 6.884 & $9.95 \pm 0.81$ \\
\hline
\end{tabular}

Table 5. Pharmacokinetic parameters of sulfamonomethoxine $(\mu \mathrm{g} / \mathrm{ml})$ following a single PO administration $(20 \mathrm{mg} / \mathrm{kg}$ ) in rabbits. (Mean \pm S.E). $(n=5)$.

\begin{tabular}{|c|c|c|c|c|c|c|c|}
\hline$\frac{\text { 히 }}{\frac{\mathrm{d}}{0}}$ & 壱 & $\frac{\text { 능 }}{\frac{0}{00}}=$ & $\frac{\text { 흥 }}{\frac{0}{0}}$ & $\frac{\text { 흥 }}{\frac{0}{0}}$ & $\frac{\text { 능 }}{\frac{0}{80}}$ & $\frac{\text { 능 }}{\frac{0}{0}}$ & 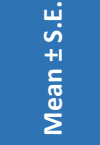 \\
\hline AUC & $\begin{array}{l}\mu \mathrm{g} / \\
\mathrm{ml} / \mathrm{h}\end{array}$ & 361.79 & $\begin{array}{l}333.1 \\
0\end{array}$ & 380.95 & 330.27 & 296.01 & $\begin{array}{l}340.42 \\
\pm 14.54\end{array}$ \\
\hline$t_{0.5(a b)}$ & $\mathrm{h}$ & 0.01 & 0.04 & 0.01 & 0.01 & 0.02 & $\begin{array}{l}0.02 \\
\pm 0.006\end{array}$ \\
\hline$t_{0.5 e l}$ & $\mathrm{~h}$ & 2.23 & 1.84 & 2.20 & 1.96 & 1.71 & $\begin{array}{l}1.99 \\
\pm 0.10\end{array}$ \\
\hline $\mathrm{CL} / \mathrm{F}$ & $\begin{array}{l}\mathrm{ml} / \mathrm{k} \\
\mathrm{g} / \mathrm{h}\end{array}$ & 0.06 & 0.06 & 0.05 & 0.06 & 0.07 & $\begin{array}{l}0.06 \\
\pm 0.003\end{array}$ \\
\hline Tmax & $\mathrm{h}$ & 0.06 & 0.23 & 0.07 & 0.10 & 0.12 & $\begin{array}{l}0.12 \pm \\
0.03\end{array}$ \\
\hline Cmax & $\begin{array}{l}\mu \mathrm{g} / \\
\mathrm{ml}\end{array}$ & 110.56 & $\begin{array}{l}114.8 \\
6\end{array}$ & 117.63 & 112.79 & 114.47 & $\begin{array}{l}114.06 \\
\pm 1.17\end{array}$ \\
\hline $\begin{array}{l}\text { Volu } \\
\text { me/F }\end{array}$ & $\begin{array}{l}\mathrm{ml} / \mathrm{k} \\
\mathrm{g}\end{array}$ & 0.18 & 0.16 & 0.17 & 0.17 & 0.17 & $\begin{array}{l}0.17 \\
\pm 0.003\end{array}$ \\
\hline $\mathrm{K}_{\mathrm{ab}}$ & $h^{-1}$ & 92.17 & 16.53 & 82.15 & 50.11 & 39.24 & $\begin{array}{l}56.04 \\
\pm 13.90\end{array}$ \\
\hline $\mathrm{K}_{\mathrm{el}}$ & $h^{-1}$ & 0.31 & 0.38 & 0.32 & 0.35 & 0.41 & $\begin{array}{l}0.35 \\
0.02\end{array}$ \\
\hline
\end{tabular}

\section{DISCUSSION}

Sulfamonomethoxine

(6-sulfanilamide-4methoxypyrimidine), a sulfanilamide with long-lasting action in a series of cases exceeds sulfadimethoxine and sulfapyridazine in therapeutic activity. Sulfamonomethoxine, normally administered via food, is widely used for therapeutic or 
prophylactic proposes for food-producing animal diseases, due to its wide spectrum of antibacterial activity and economic advantage gained from its application. It was relatively rapidly resorbed from the gastrointestinal system and circulated in the blood for a long time. (Connor, 1998)

Pharmacokinetic studies of sulfamonomethoxine after a single IV injection:

In the present study, plasma concentrations of SMM in rabbits after i.v. administration $(20 \mathrm{mg} / \mathrm{kg})$ were best described by two compartment model. The elimination half-life $\left(t_{0.5(\beta)}\right)$ was estimated to be $(2.54 \mathrm{~h})$, which was similar to the $t_{0.5(\beta)}$ of $2.5 \mathrm{~h}$ in rabbits after IV injection of $50 \mathrm{mg} / \mathrm{kg}$ reported by Bobrov et al. (1978). While Elbadawy et al. (2015) reported a shorter half-life (1h) in goat after IV administration of $10 \mathrm{mg} / \mathrm{kg}$. In contrast, Ryuji (1988) reported longer value (86.6 h) in Eel, horse (3.6h) Card et al. (1993), pig (3.11h) (Shimoda et al., 1983), tongue sole (80.4h) (Chang et al., 2014) and rainbow trout (30.9 h) or yellowtail (5.8 h) (Uno et al., 1997).

The obtained data showed that the AUC of SMM following a single IV injection of SMM $(20 \mathrm{mg} / \mathrm{kg})$ in healthy rabbits was $376.60 \mu \mathrm{g} / \mathrm{ml} / \mathrm{h}$, which higher than the data reported by Kokue et al. (1988), Shimoda et al. (1983) and Tsuboi et al. (1984) $(131,81.5$ and $186.2 \mu \mathrm{g} / \mathrm{ml} / \mathrm{h})$ in $\mathrm{pig}$, , goat $(49.9 \mu \mathrm{g} / \mathrm{ml} / \mathrm{h})$ (Elbadawy et al., 2015) and horse $(0.27 \mu \mathrm{g} / \mathrm{ml} / \mathrm{h}$ ) (Card et al., 1993), while this data was lower than data reported in tongue sole by Chang et al. (2014) $\left(1930 * 10^{3} \mu \mathrm{g} / \mathrm{ml} / \mathrm{h}\right)$ and Eel $(59.1$ $\mu \mathrm{g} / \mathrm{ml} / \mathrm{h}$ ) (Ryuji, 1988)

The present study showed that the total body clearance $(\mathrm{CL})$ of $\mathrm{SMM}$ in rabbits $(0.05 \mathrm{ml} / \mathrm{kg} / \mathrm{h})$ was higher than that in horse (0.02) (Card et al., 1993). In contrast, the (CL) of SMM in this study was lower than that reported in Eel by Ryuji (1988) $(3.38 \mathrm{ml} / \mathrm{kg} / \mathrm{h})$, tongue sole $(30 \mathrm{ml} / \mathrm{kg} / \mathrm{h})$ (Chang et al., 2014), goat $(212 \mathrm{ml} / \mathrm{kg} / \mathrm{h}$ ) (Elbadawy et al., 2015) and rabbits (Bobrov et al., 1978$)(0.06 \mathrm{ml} / \mathrm{kg} / \mathrm{h})$. These variations could be attributed to the use of a different rabbit breed and/or a different assay method. Toutain and Bousquet (2004a) reported that the pharmacokinetic profile of drugs may be substantially different between breeds of the same species.

In current study, the volume of distribution of SMM in healthy rabbits following IV injection was $0.15 \pm 0.003 \mathrm{ml} / \mathrm{kg}$, which was lower than that obtained in tongue sole by Chang et al. (2014) $(100 \mathrm{ml} / \mathrm{kg})$, Eel $(140 \mathrm{ml} / \mathrm{kg})$ (Ryuji, 1988) and horse (390 ml/kg) (Card et al., 1993), while Bobrov et al. (1978) investigated a higher value (0.23) in rabbits after IV injection of $10 \mathrm{mg} / \mathrm{kg}$. These variations could be attributed to the use of a different rabbit breed and/or a different assay method. Differences in kinetic parameters are relatively common and are frequently related to interspecies variation, age, breed, and assay used (Toutain and Bousquet, 2004b).
Pharmacokinetic studies of sulfamonomethoxine after a single oral dose administration:

In the present study, plasma concentrations of SMM in rabbits after oral administration $(20 \mathrm{mg} / \mathrm{kg})$ were best described by one compartment model. Sulfamonomethoxine was rapidly absorbed $\left(T_{\max }=0.12 \mathrm{~h}\right)$ in healthy rabbits after $\mathrm{PO}$ administration which was lower than that in pig (1.55h) (Kokue et al., 1988), horse (1.58h) (Card et al., 1993),broiler (4.39h) (Li et al., 1995), goat (5.6h) (Elbadawy et al., 2015) and tongue sole (2.5h) (Chang et al., 2014).

In current study the peak plasma concentration $\left(\mathrm{C}_{\max }\right)$ in rabbits following PO administration was $114.06 \mu \mathrm{g} / \mathrm{ml}$, which was higher than that recorded by Elbadawy et al., (2015) (2.15),pig (6.68 $\mu \mathrm{g} / \mathrm{ml})$ (Kokue et al., 1988) and horse (32.3 $\mu \mathrm{g} / \mathrm{ml}$ ) (Card et al., 1993). However, the smaller $C_{\max }$ value at $206.7 \mu \mathrm{g} / \mathrm{mL}$ has been reported in broiler (Li et al., 1995) and tongue sole $(58000 \mu \mathrm{g} / \mathrm{mL}$ ) (Chang et al., 2014).

A shorter elimination half-life of SMM was observed in rabbits $\left(\mathrm{t}_{0.5 \mathrm{el}} 1.99 \mathrm{~h}\right)$ than that in pig $(5.9 \mathrm{~h})$ (Kokue et al., 1988), horse (4.3h) (Card et al., 1993), tongue sole (95.7h) (Chang et al., 2014) and Eel (139h) (Ryuji, 1988).The area under the concentration-time curve represents the extent of drug absorption. In the present study, PO administration of SMM $(20 \mathrm{mg} / \mathrm{kg})$ to healthy rabbits showed an AUC of 340.42 $\mu \mathrm{g} / \mathrm{ml} / \mathrm{h}$, which was higher values than data reported by Kokue et al., (1988), Card et al., (1993) and Elbadawy et al.,( 2015) $(137,0.26$ and $37.5 \mu \mathrm{g} / \mathrm{ml} / \mathrm{h})$ in pig and horse. In contrast, the AUC of SMM in present study was lower than data reported in broiler by $\mathrm{Li}$ et al., (1995) $(3818 \mu \mathrm{g} / \mathrm{ml} / \mathrm{h})$, tongue sole $\left(3815^{*} 10^{3} \mu \mathrm{g} / \mathrm{ml} / \mathrm{h}\right.$ ) (Chang et al., 2014) and Eel $(28400 \mu \mathrm{g} / \mathrm{ml} / \mathrm{h})$ (Ryuji, 1988).

The obtained data showed that the volume of distribution of SMM in healthy rabbits following PO administration was $0.17 \pm 0.003 \mathrm{ml} / \mathrm{kg}$, which was lower than that obtained in horse by Card et al., (1993) $(460 \mathrm{ml} / \mathrm{kg})$. The total body clearance $(\mathrm{CL})$ of SMM in rabbits $(0.06 \pm 0.003 \mathrm{ml} / \mathrm{kg} / \mathrm{h})$ was higher than that in horse (0.02) (Card et al., 1993).

\section{REFERENCES}

BOBROV, V. I., YAKOVLEV, V. P. \& RUDZIT, É. (1978): Mechanisms of sulfamonomethoxine circulation in the rabbit. Pharmaceutical Chemistry Journal, 12, 428-431 \%@ 0091-150X.

CARD, S., SONZOGNI, O., VILLA, R., BIGNAZZI, R. \& MONTESISSA, C. (1993): Pharmacokinetic profile of sulphamonomethoxine-trimethoprim in horses after intravenous, intramuscular and oral administration. Research in Veterinary Science, 54, 184-188 \%@ 0034-5288.

CHANG, Z.-Q., LI, Z.-X., LI, J.-B., WANG, Y.-Z. \& LI, J. (2014): Pharmacokinetics of sulfamonomethoxine in tongue sole (Cynoglossus semilaevis) after intravenous and oral administration. Fish Physiology and Biochemistry, 40, 1275-1279\%@0920-1742.

CONNOR, E. E. (1998): Sulfonamide antibiotics. Primary care updates for ob/gyns, 5, 32-35 \%@ 1068-607X. 
ELBADAWY, M., SAKIYAMA, T., ABOHATAB, R., SASAKI, K. \& SHIMODA, M. (2015): Oral pharmacokinetics of the acidic drugs, diclofenac and sulfamonomethoxine in male Shiba goats. J. Vet. Med. Sci, 77, 21-6.

KOKUE, E., SHIMODA, M., SAKURADA, K. \& WADA, J. (1988): Pharmacokinetics of oral sulfa drugs and gastric emptying in the pig. Journal of Pharmacobio-Dynamics, 11, 549-554 \%@ 0386-846X.

LI, T., QIAO, G. L., HU, G. Z., MENG, F. D., QIU, Y. S., ZHANG, X. Y., GUO, W. X., YIE, H. L., LI, S. F. \& LI, S. Y. (1995): Comparative plasma and tissue pharmacokinetics and drug residue profiles of different chemotherapeutants in fowls and rabbits. J Vet Pharmacol Ther, 18, 26073.

OKERMAN, L. (1994): Diseases of the digestive system. Diseases of Domestic Rabbits, 71-91.

RONALD, A. (2003): The etiology of urinary tract infection: traditional and emerging pathogens, Disease-a-Month. 49, 71-82.

RYUJI, U. (1988): Pharmacokinetics and bioavailability of Sulfamonomethoxine in cultured Eel. Fish Pathology, 33, 297-301.
SHIMODA, M., TSUBOI, T., KOKUE, E.-I. \& HAYAMA, T. (1983): Dose-dependent pharmacokinetics of intravenous sulfamonomethoxine in pigs. The Japanese Journal of Pharmacology, 33, 903-905 \%@ 0021-5198.

TAČIĆ, A., NIKOLIĆ, V., NIKOLIĆ, L. \& SAVIĆ, I. (2017): Antimicrobial sulfonamide drugs. Advanced Technologies, 6, 58-71.

TOUTAIN, P.-L. \& BOUSQUET, M.-A. (2004a): Plasma clearance. Journal of Veterinary Pharmacology and Therapeutics, 27, 415-425 \%@ 0140-7783.

TOUTAIN, P.-L. \& BOUSQUET, M.-A. (2004b): Volumes of distribution. Journal of Peterinary Pharmacology and Therapeutics, 27, 441-453 \%@01407783.

TSUBOI, T., KOKUE, E. I., SHIMODA, M. \& HAYAMA, T. (1984):Pharmacokinetic analysis of plasma concentration and urinary excretion of sulphamonomethoxine and its metabolite in Goettingen minipigs. Journal of veterinary pharmacology and therapeutics, 7, 219-223 \%@ 0140-7783.

UNO, K., AOKI, T., UENO, R. \& MAEDA, I. (1997): Pharmacokinetics and metabolism of sulphamonomethoxine in rainbow trout (Oncorhynchus mykiss) and yellowtail (Seriola quinqueradiata) following bolus intravascular administration. Aquaculture, 153,1-8 \%@ 0044-8486 